distribution may be expected at the edge of a species range, but it may also reflect an irregular distribution of a particular bog environment favorable to the establishment and growth of this species. The occurrence in this bog of other species of limited distribution in this general region, including Drosera linearis, Sarracenia purpurea, and Carex pauciflora, also suggest that this bog is unusual in some way. It is unknown why this bog supports certain southerrn and eastern bog species which are generally uncommon or absent elsewhere in northern Saskatchewan. In the case of Arethusa it may be as simple as a smaller rodent population which reduces the amount of predation on Arethusa corms. However, it is more likely to be influenced by a complex of climatic, physiographic, biotic, and phytogeographic factors. A detailed study of the distribution of bog species and the bog habitat in Saskatchewan will help to answer this question.
The distribution of Arethusa bulbosa is primarily eastern American. It occurs throughout New England southward into the mountains of the Carolinas and westward through the Lake States to Minnesota. In the north it ranges from Newfoundland, Nova Scotia, and New' Brunswick westward to Manitoba, and, now, Saskatchewan. Its distribution in Manitoba and Saskatchewan (see map) suggests that it could be expected to occur throughout some of the boreal forest region between The Pas and Lake Athabasca. Exploration of bogs in northern Saskatchewan, particularly in the vicinity of the Hansen Lake Road and the Churchill River Road, may fill a gap in our knowledge of the distribution and ecology of Arethusa bulbosa.

\section{LITERATURE CITED}

CORRELL, D. 1950. Native orchids of North America north of Mexico. Chronica Botanica Co., Waltham, Mass.

SCOGGAN, H. J. 1957. Flora of Manitoba. Nat. Mus. Canada Bull. 140.

\title{
Plants of Eroded Hillsides
}

\section{by K. F. Best, Swift Current}

Still dealing with our dry hillsides and eroded areas, perhaps. we should take care lest we become like the man who could not see the forest for the trees. On our hills, two plants in particular are found in great pro- fusion, but we often fail to notice them. One is a small moss-like species, the other, a mat-forming phlox.

Although not generally noticed, one of the commonest and most

\section{PRAIRIE SELAGINELLA}

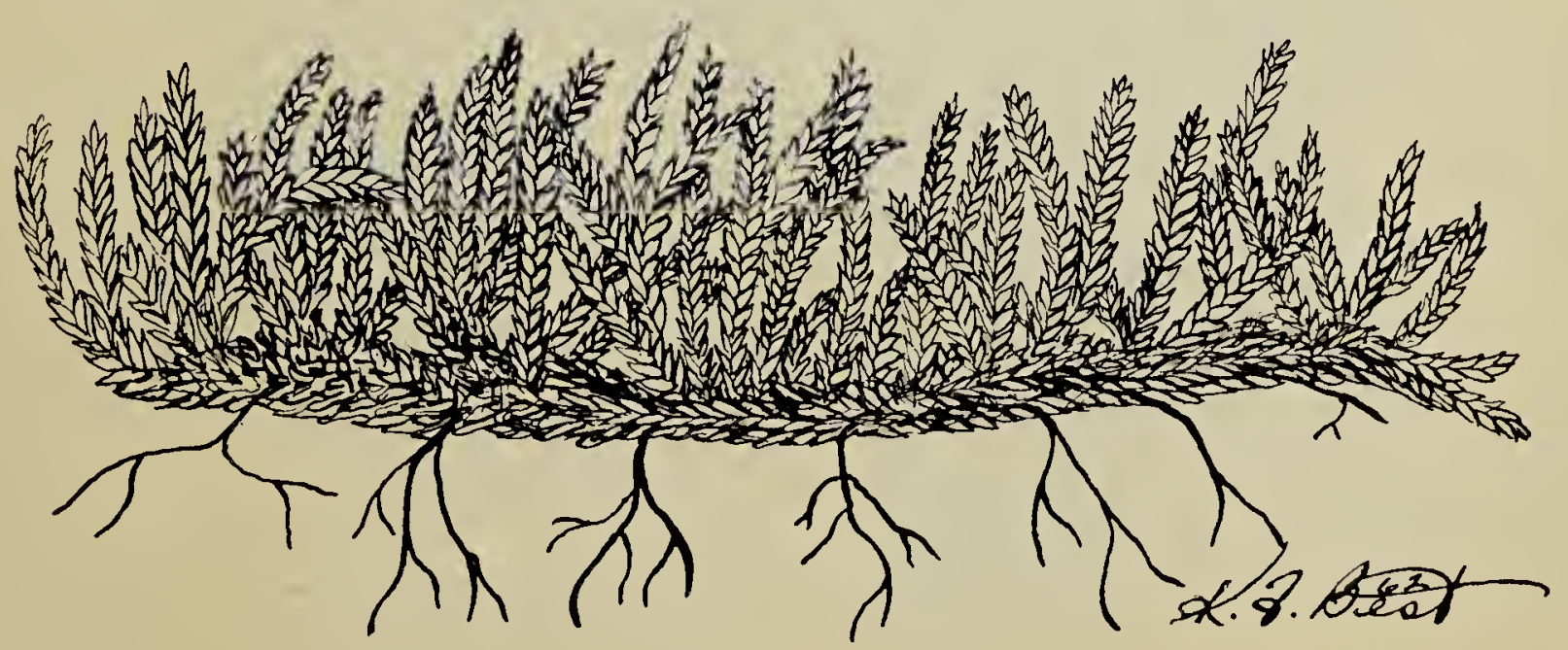


dominant plants of the drier and more open prairie is the Prairie Selaginella (Selaginella densa). Belonging to the Spikemoss family, this little Club-moss, as it is sometimes called, forms low dense mats with the stems rooting along most of their entire length. The leaves are tiny, up to $1 / 8$ inch long, each being tipped with a small bristle. The fruiting spikes are $3 / 8$ to 1 inch long and covered with green, shingle-like bracts. The spore containers appear singly in the axils of these bracts. Having no forage value, it increases cn native range undier conditions of abuse such as from overgrazing. It may serve to arrest soil erosion and perhaps helps build up the soil by adding organic matter.

Moss Phlox (Phlox hoodii) belongs to a group of plants almost exclusive to the North American continent. Phlox, meaning flame (referring to showy, brightly colored flowers), was an old Greek name for campion
(Lychnis) and was transferred to this genus by Linnaeus.

The majority of western phloxes occur in open situations, on rather dry and often gravelly or rocky soils, frequently in grass types in full sunlight. They are very showy, often growing in masses, and reproducing by seed or by creeping rootstocks.

One of the most conspicuous of our early spring flowers, the Moss Phlox forms large masses of color on the dry plains and hillsides. It is a low, tufted, mat-forming plant with coarse, woody roots. The leaves $1 / 8$ to $3 / 8$ inch long, are sharp pointed, shaped like an awl, and overlap like shingles. The flowers, although generally white, are sometimes pale blue or purple, and are about $3 / 8$ inch across with 5-petal lobes. After flowering, the plants are rather inconspicuous, although they do form a large part of the ground cover often helping to stabilize eroded areas or where the soil is shallow.
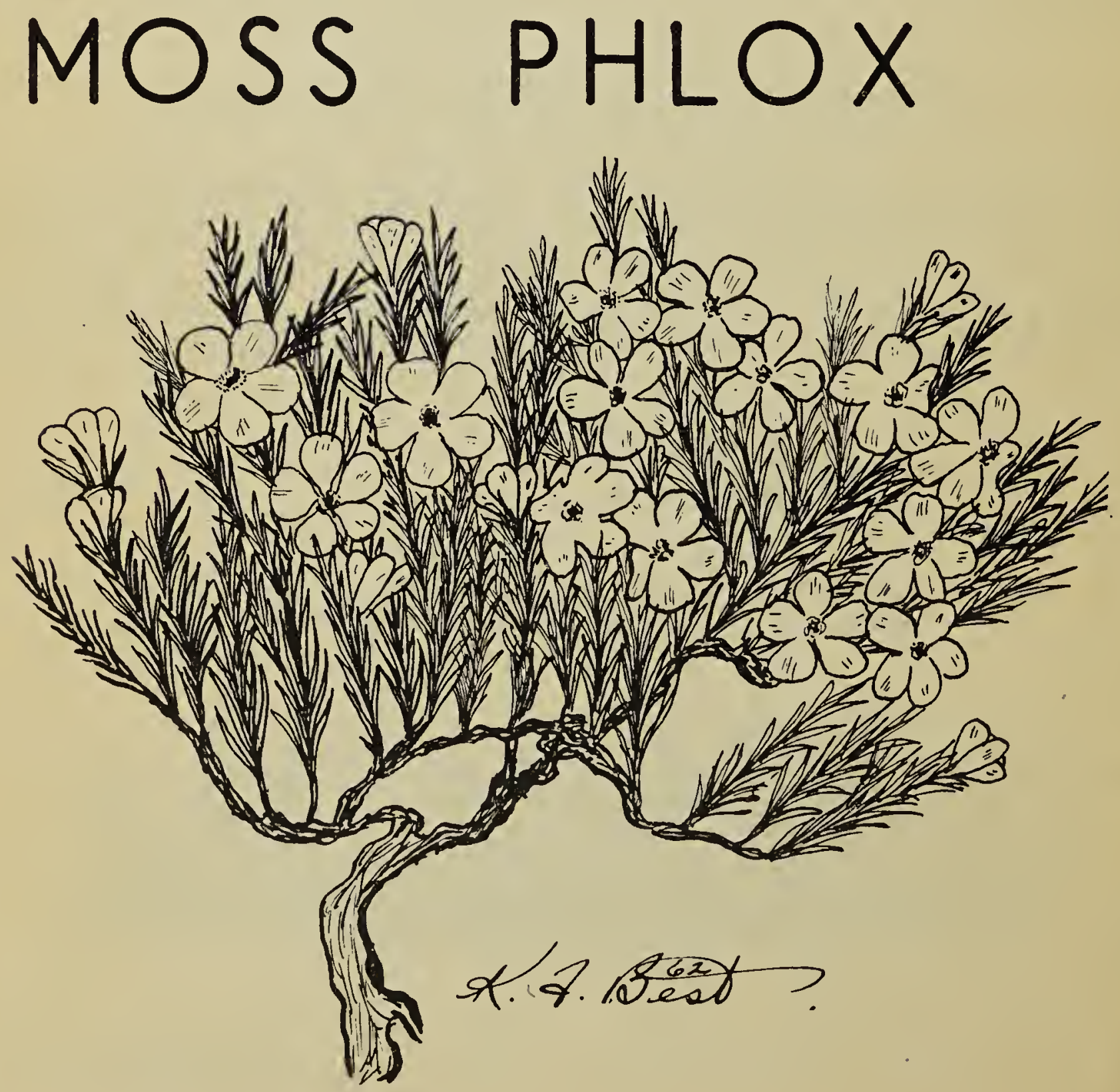